\section{THE ENGINEERING FOUNDATION}

THE annual report for 1938-1939 of the 1 Engineering Foundation of New York forms an interesting record of a year's activity in a wide range of research projects mainly of a technical nature, associated with engineering and designed to produce results of practical value to science, industry and public welfare. These researches are carried out in collaboration with engineering and other societies and the results are published by the institutions concerned and by the technical press. The part played by the Engineering Foundation is that of receiving applications for assistance, examining the merits of the projects submitted, recommending and making grants and maintaining contact with the work while in progress.

The present report records a number of researches undertaken and in progress in conjunction with seven other corporate bodies dealing with such important subjects as soil mechanics, critical pressure steam generation, cotton seed processing, and plastic flow of concrete. On the non-technical side, the Engineers' Council for Professional Development was supported in the establishment of central and local committees to deal with such matters as the selection and guidance of engineering students, engineering schools, professional training and professional recognition, the general trend and purpose of the labours of which is towards the raising of the status of the engineering profession.

The Engineering Foundation was established in 1914 "for the furtherance of research in science and engineering or for the advancement in any other manner of the profession of engineering and the good of mankind" and has now completed twenty-five years of useful service. The occasion is celebrated by the issue of a more comprehensive record of the work done during this period which gives particulars of no less than seventy-three major researches and projects which have received grants towards a total cost of more than three million dollars. This is a very remarkable result, more particularly when it is considered that the whole machinery had to be set in motion in the early years of the period. Of the grants made, a substantial portion has been devoted to matters associated with engineering instruction and the promotion of summer schools.

The report concludes with a statement of the increasing need for research. The policy of the Board has all along been one of giving aid to promising projects which otherwise would not have been undertaken because they did not fit into the programmes of other research agencies or because of lack of sufficient funds. Universities have the facilities for investigation but there may be no funds for a particular inquiry. On the other hand, scientific societies may have funds available but be without any research facilities. Again, an industrial concern may hesitate to undertake an investigation the results of which would be used by the whole industry. Such cases provide the kind of opportunity for which the Engineering Foundation exists, in order to deal with the problems and to promote their solution. Much as has been accomplished by the prudent use of the income derived from its endowments, much more remains to be done and the opportunities for productive research are constantly increasing. The Board of the Engineering Foundation looks forward to giving assistance in the work of the future and, by the help of further endowments, to be able to extend the range of its work and its grants.

\section{APPOINTMENTS VACANT}

APpLICATIONS are invited for the following appointments on or before the dates mentioned

DrRector of Eddcation-The Town Clerk, Town Hall, Stretford, Lancs. (endorsed 'Director of Education') (July 20).

Demonstrator in Physios-The Dean, Medical School Office, Guy's Hospital, Sherwood Park, Tunbridge Wells.

\section{REPORTS AND OTHER PUBLICATIONS}

(not included in the monthly Books Supplement)

Great Britain and Ireland

University College of Wales : Welsh Plant Breeding Station. War Food Production, Advisory Bulletin No. 1: Re-Grassing, an Essential Part of Food Production. By Sir R. George Stapledon. Pp. 40. Department of Scientiflc and Industrial Research. The Principles of Fumigation of Insect Pests in Stored Produce. Pp. iii +28. (London: H.M. Ftationery Office.) $6 d$, net.
[116 Metallurgical Abstracts (General and Non-Ferrous). Vol. 6, 1939 New Series). Fdited by S. C. Guillan. Pp. viii +684 . (London : Institute of Metals.) Inclnding 2 vols. of the "Journal", £4. [136 Proceedings of the Royal Society of Edinburgh, Session 1939-1940. vol. 60, Part 2, No. 11: Reciprocity, Part 3: Reciprocal Wave Functions. By Prof. Max Born and Dr. Klaus Fuchs. Pp. 141-146. 6d. Vol. 60, Part 2, No. 12: Reciprocity, Part 4: Splnor Wave Functions. By Dr. Klaus Fuchs. Pp. 147-163. 1s. 6d. Vol. 60, Part 2, of Mutations in Drosophila melanogaster. By Dr. Charlotte Auerbach. of Mutations in Drosophila melanogaster. By and Son, Ltd. ; Iondon:
Pp. I64-173. 18. (Edinburgh : Robert Grant and So

[136

Caradoc and Severn Valley Field Club. Record of Bare Facts for the Year 1939: a List of the More Noteworthy Observations made by Members of the Caradoc and Severn Valley Field Club and Others. Pp. 50. (Shrewsbury : Caradoc and Severn Valley Field Club.) [136
Transactions of the Institution of Chemical Engineers. Vol. 17, 1939. Pp. vi+202. (London: Institution of Chemical Engineers.) [176

\section{Other Countries}

Uganda Protectorate. Annual Report of the Forest Department for the Year ended 31st December 1939. Pp. 27. (Entebbe: Government Printer.) 28 .

$[106$

Report of the Institute of Scientific Resparch, Manchoukuo. Vol. 4, No. 3: The Effect of Inoculation and Fertilizer Treatments on the Yield of Soybean. By Hisien Wu Cheng and Takao Ogasa. Pp. 25-30. 20 sen. Vol. 4, No. 4: Azotobacter in the Soil of Manchuria (Report 1). By Hsien Wu Cheng. Pp. 31-60. 40 sen. (Hsinching: Institute of
Scientific Research.)
[106

U.S. Department of the Interior: Office of Education. Pamphlet No. 88 : One Dollar or Less; Inexpensive Books for School Libraries. By Edith A. Lathrop. Pp. iii + 16. (Washington, D.C. : Government Printing Office.) 5 cents.

Proceedings of the United States National Museum. Vol. 88, No. 3081 : Notes on some Pedunculate Barnacles from the North Pacific. By Dora Priaulx Henry. Pp. 225-236. (Washington, D.C.: Govern-
ment Printing Office.)

[116

Annals of the Royal Botanic Garden, Calcutta. Vol. 14 : An Account of the Genus Dioscorea in the East. Part 2: The Species which Twine to the Right; with Addenda to Part 1, and a Summary. By D. Prain and I. H. Burkill. Pp. viii $+211-528+x x+$ plates 86-150. (Alipore :
[116 Cornell University: Agricultural Experiment Station. Bulletin Cornell 723 : Wax Emulsions for Vegetables. By Hans Platenius. Pp. 44. 40. Bulletin 725 : The Value of Corn Gluten Meal for Feeding Poultry. 40. Bulletin 725 : The Value of Corn Gluten Meal for Feeding Poultry By R. C. Ringrose, L. C. Norris and G. F. Heuser. Pp. 18. Bulletin 726 : Results of Farm-Mortgage Financing in Eleven Counties in New York State. By Stanley W. Warren. Pp. 20. Bulletin 727: An Fy M. D. Woodin. Pp. 52. Memoir 227: The Fffect of Sulfur Dioxide on the Nutritive Value of Alfalfa $\mathrm{Hay}$. By J. K. Loosli, B. $\mathrm{K}_{\text {. Richards, }}$ Jr. I. A. Maynard and $\mathrm{I}_{\text {. }}$ M. Massey. Pp. 40. Memoir 228: The

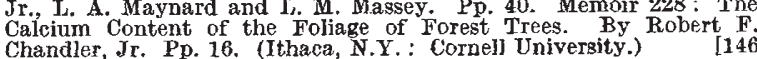
Chandler, Jr. Pp. 16. (Ithaca, N.Y. : Cornell University.) 1146
U.S. Department of the Interior: Office of Education. Pamphlet U.S. Department of the Interior: Office of Education. Pamphlet
No. 92 : Are the One-Teacher Schools Passing ? 18 Years of History. By W. H. Gaumnitz. Pp. iii +17. (Washington, D.C.: Government Printing Office.) 5 cents. [146

Proceedings of the American Philosophical Society. Vol. 82, No. 1 : Symposium on the Totalitarian State from the Standpoints of History, Political Science, Economics and Sociology, November 17, 1939. Pp. 102. (Philadelphia : American Philosophical Society.) 75 cents. [146 Bulletin of the American Museum of Natural History. Vol. 77, Art. 1: Herpetological Results of the Verney Angola Expedition, with Notes on African Reptiles in Other Collections. Part 1: Snakes, including an Arrangement of African Colubridæ. By C. M. Bogart Pp. 108+1 plate. (New York: American Museum of Natura]
History.)

Canada: Department of Mines and Resourees : Bureau of Mines, Investigations in Ore Dressing and Metallurgy, July to Decembe 1938. Pp. iv +132. (Ottawa: King's Printer.) 50 cents. [176 